\title{
Filter leaching of salt soils of automobile roads
}

\author{
Rashidbek Hudaykulov ${ }^{1 *}$, Dilfuza Makhmudova ${ }^{1}$, Dilshod Kayumov ${ }^{1}$, and Olmos Zafarov ${ }^{2}$ \\ ${ }^{1}$ Tashkent State Transport University, Tashkent, Uzbekistan \\ ${ }^{2}$ Jizzakh Polytechnic Institute, Jizzakh, Uzbekistan
}

\begin{abstract}
Globally, in arid regions, due to the irrational use of water resources for irrigating plants, salinization of soils occurs, which causes significant damage to the country's economy. In particular, recently in some regions of Uzbekistan, there has been a rise in groundwater and flooding of territories. In these areas, where the soil bases of highways contain such readily soluble salts as: $\mathrm{NaCL}, \mathrm{Na}_{2} \mathrm{SO}_{4} \cdot 10 \mathrm{H}_{2} \mathrm{O}, \mathrm{MgSO}_{4} \cdot 7 \mathrm{H}_{2} \mathrm{O}$, $\mathrm{MgCL}_{2} \cdot 6 \mathrm{H}_{2} \mathrm{O}, \quad \mathrm{CaCL}_{2} \cdot 6 \mathrm{H}_{2} \mathrm{O}, \quad \mathrm{NaHCO}_{3}, \mathrm{Na}_{2} \mathrm{CO}_{3} \cdot 10 \mathrm{H}_{2} \mathrm{O}, \quad \mathrm{CaCO}_{3}$ and $\mathrm{CaSO}_{4} \cdot 2 \mathrm{H}_{2} \mathrm{O}$, additional suffusion precipitation is often observed which lead to deformations of road surfaces. Additional precipitation is due to the dissolution of salt crystals upon ingress of moisture during filtration leaching. Filtration leaching of soils was carried out in the F-1M device according to the upward flow pattern. To determine the amount of leached salts during the experiment, the infiltrate was taken, its volume and mineralization were recorded. At the end of the tests, the soil was tested according to the general scheme. To assess the influence of the leaching process on the strength indices of the studied soils by the methods of consolidated and fast shear, tests of pre-leached samples were performed. When testing soils, samples were cut, pre-compacted with the same specified load, and leached for a month. In laboratory conditions, the deformation modulus was determined by performing compression experiments. In connection with a sharp change in the modulus of deformation of soils during moistening, the tests were carried out at two values of humidity: at natural and after water saturation without the possibility of swelling. The study results show that the deformation modulus of water-saturated loams satisfactorily correlates with the value of the initial porosity coefficient and decreases as a result of water saturation and leaching. The degree of decrease depends on the value of the initial deformation modulus: the higher it is, the more significant its change. The value of the coefficient of weakening of the soil structure depends on the effective average pressure. The criterion for the permissible salt content in the base of the roadbed of highways should be taken not only the value of the degree of salinity but also the change in the indicators of the mechanical properties of soils used in the design of the construction of the roadway during soaking and leaching.
\end{abstract}

*Corresponding author: rashidbek_19_87@mail.ru 


\section{Introduction}

Currently, in the developed countries of the world, the study of the effect of salts on the engineering and geological properties of soils and the physical and mechanical properties of building materials is carried out in the leading scientific centers of the world. In particular, such as determination of the effect of salts on the physical and mechanical properties of soils; identification of the aggressive effect of salts on the performance of building materials and protection of underground parts of buildings and structures from the aggressive effects of salts; development of methods for determining the mechanical characteristics of saline soils; zoning of saline areas. All this, in turn, allows us to develop recommendations for reliable design, construction, and operation of buildings and structures on saline soils [1-8].

The experience of designing and building highways in Uzbekistan shows that when designing and building in zones where saline soils are spread, it is necessary to consider the variability of the material composition, structure, and physical and mechanical properties of soils in the process of water saturation and leaching.

It should be noted that the rise of the groundwater level and the soaking of the soil of the base of the roads causes uneven precipitation, which leads to the unevenness of the surface. Analysis of the deformation state of some roads located on territories composed of saline soils of Bukhara, Jizzakh, Kashkadarya, Syrdarya, Surkhandarya, Fergana, and Khorezm regions and the Republic of Karakalpakstan showed that when predicting changes in the properties of soils of the road base, factors affecting the physical-mechanical properties, for example, long-term water filtration, salt composition, etc.

Many methodological guidelines and normative literature provide recommendations for determining the mechanical properties for soils saline with readily and moderately soluble salts [9-20], and issues of assessing the physical and mechanical properties of saline soils during prolonged water saturation and leaching, i.e., water filtration has not been sufficiently researched.

As a result of prolonged exposure to fresh water on saline clay soil, not only strongly and moderately soluble salts (chlorides, sulfates) are removed, but also poorly soluble compounds (carbonates, silica, iron oxides), which are natural cements of soils, which determine their strength and deformation properties [21-29]. Therefore, removing or weakening these natural cements changes the composition and structure of soils and determines the change in their properties.

The aim of the study is to study the regularities of changes in the mechanical properties of saline soils used in the design of the structure of motor vehicles during soaking and prolonged filtration of water.

\section{Methods}

To assess the effect of water saturation and leaching processes on the properties of saline soils, samples were taken from highways in characteristic sections of the Syrdarya region 4P33 "Ulyanova-Naiman (Gulistan-Gagarin $18 \mathrm{~km}$ )" (Fig. 1) and the Republic of Karakalpakstan "Khalkabad- Kegeyli, $3 \mathrm{~km}$ ". The characteristics of natural saline soils, determined in laboratory conditions, are shown in tables 1 and 2. Laboratory tests of soils were carried out according to the current standard methods. Static processing was carried out on them. 


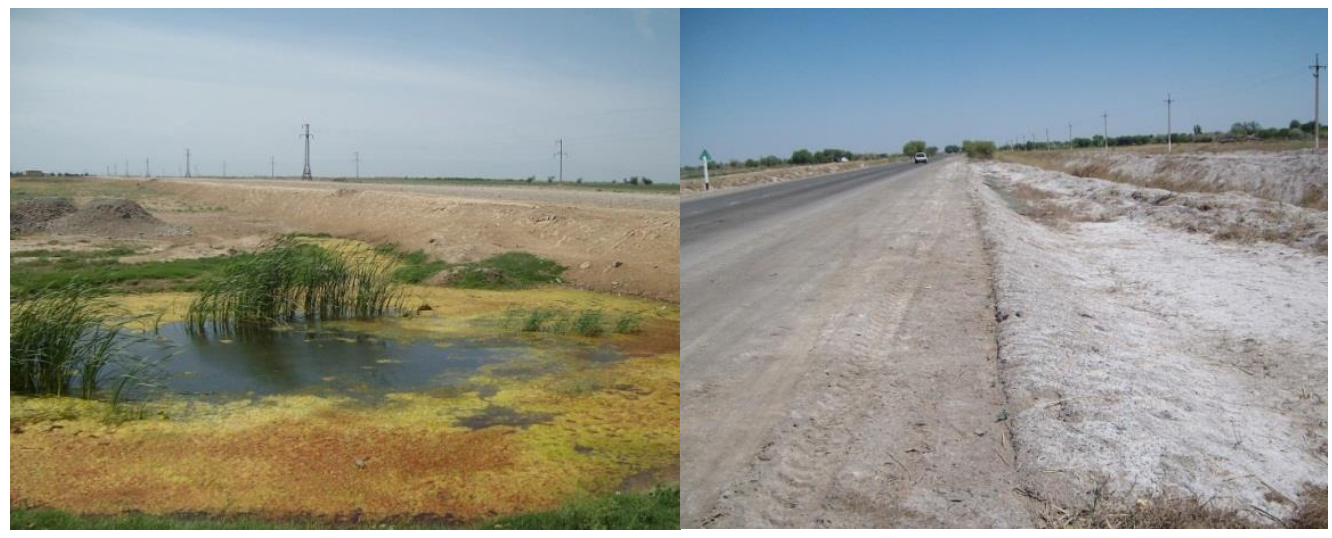

Fig. 1. Highway 4P33 "Ulyanova-Naiman (Gulistan-Gagarin 18 km)"

Fig. 2. Khalkabad-Kegeili highway, 3 km

Table 1. Typical properties of saline soils of the surveyed roads

\begin{tabular}{|c|c|c|c|c|c|c|c|c|}
\hline № & Place of selection & 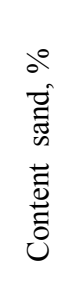 & 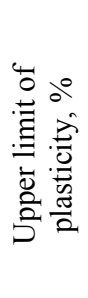 & 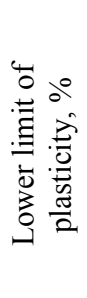 & 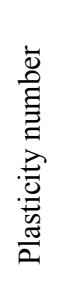 & 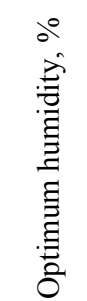 & 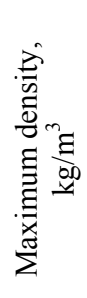 & $\begin{array}{l}\text { Name } \\
\text { of soils }\end{array}$ \\
\hline 1 & $\begin{array}{c}\text { Syrdarya region, } \\
\text { 4R33 "Ulyanovo- } \\
\text { Naiman (Guliston- } \\
\text { Gagarin } 20 \mathrm{~km}) "\end{array}$ & 16.6 & 29 & 23 & 6 & 17.60 & 1770 & $\begin{array}{c}\text { Heavy } \\
\text { silty } \\
\text { sandy } \\
\text { loam }\end{array}$ \\
\hline 2 & $\begin{array}{c}\text { Karakalpak } \\
\text { Republic } \\
\text { "Khalkabad- } \\
\text { Kegeili Highway, } 3 \\
\text { km" }\end{array}$ & 12.1 & 32 & 21 & 15 & 20.50 & 1720 & $\begin{array}{c}\text { Heavy } \\
\text { silty } \\
\text { loam }\end{array}$ \\
\hline
\end{tabular}

Table 2. Salt content in natural soils, \%

\begin{tabular}{|c|c|c|c|c|c|c|c|c|}
\hline № & 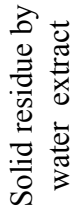 & 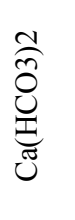 & $\begin{array}{l}\text { O } \\
\text { WD } \\
\sum^{\infty}\end{array}$ & $\begin{array}{l}\bar{U} \\
\bar{Z}\end{array}$ & $\begin{array}{l}\text { O } \\
\text { N } \\
\tilde{Z} \\
z\end{array}$ & $\begin{array}{l} \pm \\
0 \\
\tilde{U} \\
\tilde{U}\end{array}$ & 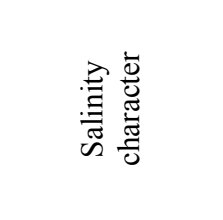 & 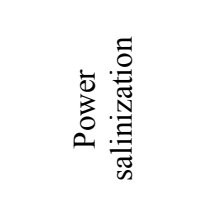 \\
\hline 1 & 5.11 & 0.01 & 0.35 & 3.20 & 0.05 & 1.49 & Sulfate-chloride & Strongly salty \\
\hline 2 & 1.34 & 0.01 & 0.07 & 0.15 & 0.23 & 60.95 & Sulfate & Medium salted \\
\hline
\end{tabular}

Filtration leaching of soils was carried out in the F-1M device according to the upward flow pattern. A sample of the natural constitution, previously tested according to the above- 
described scheme, was placed into the device. To eliminate wall filtration, the lateral surfaces of the sample were processed according to the technique proposed by V.P. Petrukhin [30]. The sample was cut with a smaller diameter relative to the ring of the F-1M instrument $\left(S=50 \mathrm{~cm}^{2}\right)$. A thin layer of plastic glue was applied to its lateral surfaces, and the gap between the ring and the sample was filled with paraffin. Such processing makes it possible to assume that the movement of the liquid occurs exclusively through the volume of the soil.

Water filtration was carried out under high pressure gradients (up to $J=100$ ) created by the water column. At the same time, its limiting value was set not at a time but constantly, in steps $(J=10,30,60,100)$. To determine the amount of leached salts during the experiment, the infiltrate was taken, its volume and mineralization were recorded. At the end of the tests, the soil was tested according to the general scheme.

The result of the experiment on filtration leaching of soil was the analysis of its effect on changes in the mechanical properties of the studied soils.

To obtain the strength characteristics of the studied soils, single-plane shear devices with a fixed shear plane of the Hydroproject system were used. To assess the influence of the leaching process on the strength indices of the studied soils by the methods of consolidated and fast shear, tests of pre-leached samples were performed. When testing soils, samples were cut, pre-compacted with the same specified load $\left(P_{w}=0.0 ; 0.1 .5 ; 0.2\right.$; $0.3 \mathrm{MPa}$ ) and leached for 1-1.5 months.

To obtain a comparative characteristic of the strength of soils, the method of penetration with a laboratory cone with a tapered indenter angle of $30^{\circ}$ was used. Penetration tests were carried out according to the scheme of gradual (stepwise) loading of the cone with increasing loads with simultaneous registration of the immersion depth (with an accuracy of $0.1 \mathrm{~mm})$.

Creep tests of specimens were carried out in shear devices of the Hydroproject system according to the method of N.N. Maslova and Z.M. Karaulova [31].

In laboratory conditions, the deformation modulus was determined by carrying out compression experiments $[32,33]$. In connection with a sharp change in the deformation modulus of soils during moistening, to obtain a complete characterization of deformability, tests were carried out at two values of humidity: at natural and after water saturation without the possibility of swelling.

Compression tests were performed using the 2-curve method. One branch at a time - on naturally moist soils at $P=0.0 ; 0.05 ; 0.1 ; 0.15 ; 0.2 ; 0.25$ and $0.3 \mathrm{MPa}$, with saturation at $P$ $=0.3$ and $0.5 \mathrm{MPa}$. $\mathrm{MPa}$.

On the second branch - with saturation at Rbyt, followed by bringing the loads to 0.3

\section{Results and Discussion}

To assess and predict the deformation modulus of water-saturated sandy loam and loamy soils, an analysis of the results of compression studies was carried out. The results of the correlation-repression analysis are shown in table 3. 
Table 3. Dependence of the deformation modulus of loam on the initial porosity coefficient

\begin{tabular}{|c|c|c|c|c|}
\hline \multirow[t]{2}{*}{ № } & \multirow{2}{*}{$\begin{array}{l}\text { Pressure range, } \\
\mathrm{MPa}\end{array}$} & \multirow[t]{2}{*}{ Humidity } & $\begin{array}{l}\text { Deformation modulus } \\
\text { range }\end{array}$ & \multirow{2}{*}{$\begin{array}{l}\text { Correlation } \\
\text { coefficient }\end{array}$} \\
\hline & & & porosity coefficient & \\
\hline 1 & $0-0.3$ & Natural & $\frac{3 \div 20}{0.64 \div 0.94}$ & 0.10 \\
\hline 2 & $0-0.3$ & water saturated at $\mathrm{P}=0$ & $\frac{2.5 \div 9.0}{0.64 \div 0.94}$ & 0.66 \\
\hline 3 & $0-0.5$ & Natural & $\frac{4 \div 20}{0.78 \div 1.03}$ & 0.70 \\
\hline 4 & $0-0.5$ & water saturated at $\mathrm{P}=0$ & $\frac{2.5 \div 4.7}{0.73 \div 1.00}$ & 0.71 \\
\hline
\end{tabular}

It can be seen from the data presented that the deformation modulus of water-saturated loams satisfactorily correlates with the value of the initial porosity coefficient. Whereas for loam of natural moisture, there is no dependence of the deformation modulus on the porosity coefficient (for the pressure range of $0-0.3 \mathrm{MPa}$ ), there is a significant scatter of data. This circumstance can be explained by the fact that the water saturation of the soil largely neutralizes the features of the structure, weakening the structural bonds $[34,35]$.

To characterize the change in the deformation modulus during soil water saturation, it is recommended [35] to use the structure weakening coefficient, i.e., the ratio of the deformation modulus at natural moisture and after water saturation:

$$
K_{\text {O.c. }}=\frac{E^{e}}{E^{z}}
$$

where: $E^{e}$ and $E^{z}$ are the values of the deformation moduli at natural humidity and after soaking, respectively; $K_{\text {o.c. }}$ is structure weakening coefficient.

The coefficient of weakening of the soil structure at water saturation satisfactorily correlates with the degree of water saturation (see table 4).

From table 4 , it is clearly seen that additional water saturation of loam with a water saturation degree of $S_{r}=0.6-0.7$ does not lead to further weakening of the structure. Further weakening of the structure of water-saturated soils can only be due to the dissolution and removal of solid structural elements. Thus, in soils with a degree of water saturation $S_{r} \geq 0.7$ soaking practically does not change the value of the deformation modulus.

Table 4. Dependence of the attenuation coefficient of the loam structure on the degree of water saturation

\begin{tabular}{|c|c|c|c|c|}
\hline № & $\begin{array}{c}\text { Pressure range, } \\
\mathrm{MPa}\end{array}$ & $S_{r}$ & $K_{\text {o.c. }}$ & $\begin{array}{c}\text { Correlation } \\
\text { coefficient }\end{array}$ \\
\hline & & 0.4 & 4.8 & \\
1 & & 0.5 & 2.2 & \\
& $0-0.3$ & 0.6 & 1.2 & 0.78 \\
& & 0.7 & 1.0 & \\
\hline & & 0.8 & 0.8 & \\
\hline & & 0.3 & 3.0 & \\
& $0-0.5$ & 0.4 & 2.0 & \\
& & 0.5 & 1.5 & 0.51 \\
& & 0.6 & 1.0 & \\
\hline
\end{tabular}


According to the data of compression tests of collapsing soils at natural humidity and after water saturation at zero pressure, the value of the structure weakening coefficient shows a significantly wide range of values from 1 to $13-15$, but if we discard the obvious "rebounds" characteristic of samples of poor quality, then the range of change in the value of $K_{\text {o.c. }}$ decreases to $1-5$.

The value of the coefficient of weakening of the soil structure depends on the effective average pressure: at pressures $P<P_{\text {str }}$. value $K_{\text {o.c. }}$. varies for soils in a sufficiently wide range. But after the breaking of natural structural bonds and the formation of new structural bonds of hardening at $P>P_{f . s t r}$, the value of $K_{\text {o.c. }}$ decreases and approaches one. The value of $K_{o . c}$ is close to unity for fully water-saturated clayey soils unless leaching of the structural elements represented by soluble minerals occurs.

Table 5 shows the change in the modulus of soil deformation as a result of water saturation.

From the given data table 5 , it follows that the modulus of deformation of clay soils as a result of water saturation decreases approximately 2 times. The degree of reduction depends on the value of the initial deformation modulus: the higher it is, the more significant its change.

Table 5. Change in the modulus of soil deformation as a result of water saturation

\begin{tabular}{|c|c|c|c|c|c|c|c|}
\hline \multirow{2}{*}{ Soil } & \multirow{2}{*}{$W, \%$} & \multirow{2}{*}{$l$} & \multirow{2}{*}{$W_{T}, \%$} & \multirow{2}{*}{$W_{P}, \%$} & \multicolumn{2}{|c|}{$\begin{array}{c}\text { Deformation modulus in } \\
\text { the pressure range } \\
0-0.3 \mathrm{MPa}\end{array}$} & \multirow{2}{*}{$K_{o . c .}$} \\
\hline & & & & & $\begin{array}{c}\text { natural } \\
\text { humidity }\end{array}$ & $\begin{array}{c}\text { water- } \\
\text { saturated }\end{array}$ & \\
\hline $\begin{array}{c}\text { Heavy silty sandy } \\
\text { loam }\end{array}$ & 8 & 0.635 & 23 & 18 & 20 & 9.4 & 2.15 \\
\hline Heavy silty loam & 17 & 0.750 & 39 & 24 & 8.6 & 4.0 & 3.10 \\
\hline
\end{tabular}

\section{Results and Discussion}

The results of compression studies by the "three curves" method of loamy and sandy loam saline soils are shown in table 6 . Leaching was carried out by washing with distilled water for 25-60 days until a constant amount of removed salts in the sequentially taken samples of the filtrate was established.

Table 6. Change in the modulus of deformation of saline soils as a result of water saturation and leaching

\begin{tabular}{|c|c|c|c|c|c|c|}
\hline \multirow{2}{*}{ Soil } & \multirow{2}{*}{$\begin{array}{l}\text { Porosity } \\
\text { coefficient }\end{array}$} & \multirow{2}{*}{$\begin{array}{l}\text { Plasticity } \\
\text { number }\end{array}$} & \multirow{2}{*}{$\begin{array}{l}\text { Leaching } \\
\text { rate, } \beta\end{array}$} & \multicolumn{3}{|c|}{$\begin{array}{l}\text { Deformation modulus in the pressure } \\
\text { range } 0-0.3 \mathrm{MPa}\end{array}$} \\
\hline & & & & $\begin{array}{l}\text { natural } \\
\text { moisture }\end{array}$ & $\begin{array}{l}\text { water } \\
\text { pump. }\end{array}$ & leached \\
\hline $\begin{array}{l}\text { Heavy silty } \\
\text { sandy loam }\end{array}$ & 0.65 & 6 & 0.38 & 22 & 9.3 & 3.7 \\
\hline $\begin{array}{l}\text { Heavy silty } \\
\text { loam }\end{array}$ & 0.75 & 15 & 0.24 & 8,5 & 4.2 & 3.3 \\
\hline
\end{tabular}

The given data follows that the deformation modulus as a result of water saturation and leaching decreases from 1.46 to 6.0 times. The degree of decrease depends on the value of the initial deformation modulus: the higher it is, the more significant its change.

It should also be noted that the change in the deformation modulus depends on the degree of its leaching (fig. 3). It should be noted that the decrease in the modulus of 
deformation is due to an increase in the pore volume of the soil due to the removal of salts, which most strongly affects the compressibility of the soil during leaching.

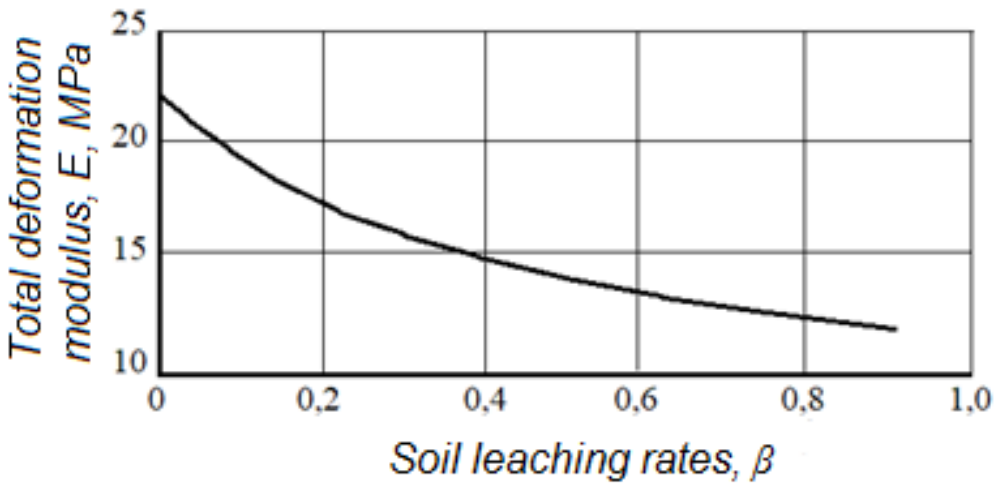

Fig. 3. Change in the moduli of the general soil deformation depending on the degree of leaching of sandy loam soil

It should be noted that the conditions for preparing the carrying out of shear tests make it possible to take into account the peculiarities of soils in the conditions of their operation in the massif to the maximum extent. In this regard, shear tests of soils were performed according to the method of N.N. Maslov [31, 32], which allows determining the parameters of strength and creep of soils and their changes under the influence of water saturation and leaching processes. The results of the studies performed are shown in table 7.

Table 7. Change in the mechanical properties of saline soils as a result of leaching

\begin{tabular}{|c|c|c|c|c|c|}
\hline \multirow{2}{*}{ Soil } & \multicolumn{2}{|c|}{$\begin{array}{r}\text { Before leaching at natural } \\
\text { moisture-density }\end{array}$} & \multicolumn{2}{|c|}{ After leaching } \\
\cline { 2 - 3 } & Clutch, MPa & $\begin{array}{c}\text { Internal friction } \\
\text { angle, } \varphi, \text { deg } \\
\text { rate } \beta\end{array}$ & Clutch, \\
$\mathrm{MPa}$ & $\begin{array}{c}\text { Internal friction } \\
\text { angle, } \varphi, \text { deg }\end{array}$ \\
\hline $\begin{array}{c}\text { Heavy silty sandy } \\
\text { loam }\end{array}$ & 0.025 & 16.5 & 0.38 & 0.018 & 11.3 \\
\hline Heavy silty loam & 0.060 & 11.5 & 0.24 & 0.037 & 7.2 \\
\hline
\end{tabular}

It should be noted that the change in the properties of soils in the process of their leaching is associated with a change in their salt complex, first of all, with a change in the amount of easily and moderately soluble salts.

\section{Conclusions}

Based on the research carried out, the following can be done:

1. The criterion for the permissible content of salts in the base should be taken not only the value of the degree of salinity but also the change in the indicators of the mechanical properties of soils during soaking and leaching.

2. The processes of water saturation and leaching significantly affect the deformation modulus, cohesion, angle of internal friction, ultimate strength, creep threshold, and viscosity coefficient of the studied soils. 
3. The degree of change in the parameters of deformation and strength is determined, first of all, by moisture, density, and disturbance of structural bonds in the course of leaching of the studied saline soils.

4. The design of highways on saline soils should include two main stages: determination of the values and nature of the decrease in mechanical properties during water saturation as a result of soaking and during leaching as a result of prolonged filtration of water; the appointment of a set of measures aimed at ensuring the reliability of the roadbed during leaching.

\section{References}

1. Agudo E., Mees F., Jacobs P., Rodriguez-Navarro C., The role of saline solution properties on porous limestone salt weathering by magnesium and sodium sulphates, Environmental geology, № 52, pp. 269-281, (2007)

2. Scientific and technical report on the topic, Assesing the impact of water-salt regime of soil on the basis of transport facilities and development of sustainable constructions in Uzbekistan, Tashkent Automobile Roads Institute (TARI), p. 154, Tashkent, (2014)

3. Angeli M., Bigas J.P., Benavente D., Menéndez B., Hébert R., David C., Salt crystallization in pores: quantification and estimation of damage, Environmental geology, 52, pp. 205-213, (2007)

4. Burns S.E., Mayne P.W. Analytical cavity expansion-critical state model for piezocone dissipation in fine-grained soils, Soils and Foundations, 42(2), pp. 131-137, (2003)

5. Li Y.P., Liu J., Yang C.H., Influence of mudstone interlayer on deformation and failure characteristics of salt rock, Chinese Journal Rock Mechanics Engineering, 25(12), pp. 2461-2466, (2006)

6. Li M.H., Kang S.C., Zheng M.P., Bu L.Z., Saline sedimentary rhythm of Qiuli'nanmu Lake in Tibet, Geology Journal China University, 13(1). - pp. 35-42, (2007)

7. Liang W.G., Yang C.H., Zhao Y.S., Dusseault M.B., Liu J., Experimental investigation of mechanical properties of bedded salt rock, International Journal Rock Mechanics, Mineral Science, № 44(3), pp. 400-411, (2007)

8. Khudaykulov, R.M. (2018) Justification of the design characteristics of saline soils of the subgrade, p.134, Tashkent, (2018)

9. Netterberg F., Loudon P., Simulation of salt damage to roads with laboratory model experiments, In Proceedings of the $7^{\text {th }}$ regional conference for Africa on soil mechanics and foundation engineering, p. 7, Accra, (1980)

10. Wu W., Yang C.H., Hou Z., Investigation on studied situations associated with mechanical aspects and development for underground storage of petroleum and natural gas in rock salt, Chin J Rock Mech. Eng. 24(S2), pp. 5561-5568, (2005)

11. Yang C.H., Li Y.P., Chen F., Shi X.L., Qu D.A., Advances in researches of the mechanical behaviors of deep bedded salt rocks in China, In Proceedings of the $43^{\text {rd }}$ U.S. rock mechanics symposium and 4th U.S.-Canada rock mechanics symposium. pp. 450-455, (2009), Asheville, (2009).

12. Xie L.Z., Zhou H.W., Xie H., Research advance of $\mathrm{CO}_{2}$ storage in rock salt caverns, Rock Soils Mechanics, 30(11), pp. 3324-3330, (2009)

13. Guideline on the Use of Sand in Road Construction in the SADC Region AFCAP/GEN/028/C, p. 81, (2013)

14. Geotechnical, Geological and earthquake engineering. Water in road structures Movement, Drainage ettects andrew dawson editor, University of Nottingham, p. 436, UK, (2008) 
15. Experimental Investigation of Water Migration Characteristics for Saline Soil, Pol. J. Environ. Stud. 28,(3) pp.1495-1505, (2019)

16. Zhang X., Wang Q., Wang G., Wang W., Chen H., Zhang Z., A Study on the Coupled Model of Hydrothermal-Salt for Saturated Freezing Salinized Soil, Mathematical Problems in Engineering, 2(1), (2017)

17. Hall, K.T. and Crovetti, J.A., Effects of Subsurface Drainage on Pavement Performance, Analysis of the SPS-1 and SPS-2 Field Sections, NCHRP Report 583, Transportation Research Board, Washington, DC, 92pp. and Annexes (2007)

18. Seed H.B., Mitchell J.K., Chan C.K. Studies of swell pressure characteristics of compacted clays. // Highway research board, 113, p. 27 (1962).

19. Whitman K.W., Pablo P.O., Densification sent by vertical vibrations, Proceeding of $4^{\text {th }}$ World Conference of Earthquake Engineering in Santiago. pp. 127-132, Chili, 1969

20. Ayroyan S.G., Regularities of changes in strength and creep of swelling soils, their prediction and the possibility of using them in construction. Abstract of the dissertation for the degree of Doctor of Geological Sciences, Yerevan, Yerevan State University, p. 52, (2013)

21. Golly O.R., Using the laws of clay swelling in construction. Reconstruction of cities and geotechnical construction. Soil mechanics, L., 8, pp. 132-141, (2004)

22. Sinyakov V.N., Trokhimchuk M.V., Evaluation of the resistance of swelling clays to water cut when predicting the degree and environmental risk, International scientific and technical conference-seminar, "Environmental Problems in Construction", pp. 5759, Heraklion, Greece (2000)

23. Braja M.D. Principles of Geotechnical Engineering. United States. p. 470, (2010)

24. David G.P. Engineering Geology principles and practice, Springer-Verlag Berlin Heidelberg, p. 450, (2009)

25. Roads and Salinity ISBN:0734753772//Department of Infrastructure, Planning and Natural Resources p. 26 (2003)

26. Building in a Saline Environment ISBN: 9780734759702//Department of Infrastructure, Planning and Natural Resources p. 18, (2008)

27. The Prevention and Repair of Salt Damage to Roads and Runways ISBN 99912-0$380-\mathrm{X} / /$ Guide to the Prevention and Repair of Salt Damage to Roads and Runways, $\mathrm{p}$. $24,(2001)$

28. International Journal of Pavement Researchand Technology ISSN 19966814//Pavement Mechanic Response of Sulfate Saline Soil Subgrade Section Basedon Fluid-Structure Interaction Model 2016 9(1) p. 19, (2016)

29. Magazyn Autostrady, Budownictwo drogowo-mostowe ISSN 17300703//Inteligentne Systemy Transportowe 5/2017, p.57

30. Petrukhin V.P. Construction of structures on saline soils, Stroyizdat, p. 264, Moscow, (1989)

31. Fundamentals of Engineering Geology and Soil Mechanics. Textbook for universities, Higher school, p. 511, Moscow, (1982)

32. Dmitriev V.V., Yarg L.A. Methods and quality of laboratory study of soils: textbook / V.V. Dmitriev, L.A. Yarg. -M .: KDU, - p. 502, Moscow, (2008)

33. Trofimov V.T., Koroleva V.A., Laboratory work on soil science. KDU, University book, p. 654 (Moscow). (2017)

34. Kazarnovsky V.D., Fundamentals of Engineering Geology, Road Soil Science and Soil Mechanics (Short Course). p. 284 Moscow, (2007)

35. Kayumov, A.D., Makhmudova, D.A., Khudaykulov, R.M. Behavior of loess soils/ Journal of Highways, 06 (991). pp.93-94, Moscow (2014) 